\title{
Development of a valid and reliable pterygium surgery assessment scale for ophthalmology residents
}

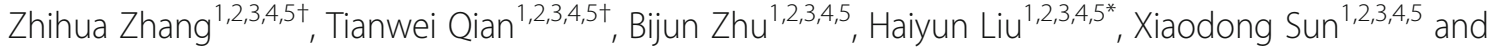 \\ Xun $X^{1,2,3,4,5}$
}

\begin{abstract}
Background: Microsurgery training has become an important part of ophthalmology teaching and one of the main topics of examination. Accurate and effective evaluation of microsurgery skills is vital for the training and teaching of residents. In this study, we aimed to establish a pterygium surgery assessment scale for use by ophthalmic residents and evaluate its reliability and validity.
\end{abstract}

Methods: Based on a literature search, experienced pterygium surgeons developed the preliminary scale according to the standard surgical procedure. The preliminary scale and a questionnaire were sent to teaching and research experts in the field for feedback. Face and content validity and reliability of the scale were determined by rounds of modifications based on expert feedback. For construct validity, existing assessment scales were obtained and a range of factors were tested.

Results: Nineteen expert surgeons completed the questionnaire and modifications were made until all surgeons agreed on the final scale. Good construct validity was found by evaluation against 257 existing scales. For reliability, 280 evaluation scales were completed. Inter- and intra-rater reliability analysis both found Intraclass Correlation Coefficient (ICC) $>0.8$ for all items and total scores.

Conclusion: The pterygium surgery assessment scale developed in this study has good reliability and validity, and is an effective measurement tool for the evaluation of ophthalmology residents' pterygium surgical skills.

Keywords: Pterygium surgery, Assessment scale, Reliability, Validity

In 2002, the American Board of Ophthalmology added surgery and surgical skills as the seventh independent category to the six categories previously defined by the Accreditation Council for Graduate Medical Education (ACGME) for evaluating competency as an educational outcome of residency programs [1]. Over time,

\footnotetext{
*Correspondence: 13901812628@163.com

${ }^{\dagger}$ Zhihua Zhang and Tianwei Qian co-first authors.

'Department of Ophthalmology, Shanghai General Hospital, Shanghai Jiao Tong University, 100 Haining Road, Hongkou District, 200080 Shanghai,

China

${ }^{2}$ National Clinical Research Center for Eye Diseases, Shanghai, China Full list of author information is available at the end of the article
}

microsurgery training has gradually become an important part of ophthalmology teaching and one of the main topics of examination for ophthalmology residency programs worldwide [2,3]. At the beginning, the evaluation of surgical skills has been based on the subjective impression of examiners with a lack of standardized evaluation, limiting the consistency and credibility of the assessment. Thus, the International Council of Ophthalmology (ICO) has established several standardized assessment scales related to cataract, strabismus, ptosis and other ophthalmic surgery, with excellent feedback and application effect [4-9]. After integrating with the

(C) The Author(s). 2021 Open Access This article is licensed under a Creative Commons Attribution 4.0 International License, which permits use, sharing, adaptation, distribution and reproduction in any medium or format, as long as you give appropriate credit to the original author(s) and the source, provide a link to the Creative Commons licence, and indicate if changes were made. The images or other third party material in this article are included in the article's Creative Commons licence, unless indicated otherwise in a credit line to the material. If material is not included in the article's Creative Commons licence and your intended use is not permitted by statutory regulation or exceeds the permitted use, you will need to obtain permission directly from the copyright holder. To view a copy of this licence, visit http://creativecommons.org/licenses/by/4.0/ The Creative Commons Public Domain Dedication waiver (http://creativecommons.org/publicdomain/zero/1.0/) applies to the data made available in this article, unless otherwise stated in a credit line to the data. 
ICO, ophthalmologists in China began to use these scales. However, they mainly focus on surgery conducted by high-level staff and not by ophthalmic residents. Therefore, for the training and teaching of surgical skills, evaluation methods for appropriate levels of surgery are needed.

Pterygium is a common ocular surface disease, the standard surgical treatment of which is pterygium excision and conjunctival autograft transplantation [10]. The procedure involves the use of instrumentation and suturing under a microscope, offering opportunities to fully assess basic microsurgical skills. Therefore, in Shanghai, pterygium surgery is mandated as a periodical exam in the residency program. Accurate and effective evaluation of this procedure is vital for the training and teaching of residents $[11,12]$, but no appropriate standardized evaluation scale exists in China. We previously developed an efficient and reliable scale for the assessment of corneal suture technique [13]. In the present study, we aim to establish a similar scale for pterygium surgery to evaluate the surgical competency of residents and improve traditional ophthalmic surgery teaching methods.

\section{Methods and materials}

\section{Development of the assessment scale}

Two surgeons highly experienced in pterygium surgery developed the scale on the basis of a literature search and knowledge of the standard surgical procedure. Scale design took into consideration the examination syllabus with the aim of ensuring that the scale could assess basic surgical skills, pterygium dissection and ocular surface reconstruction. Any discrepancies between the two surgeons were discussed with a third person to develop the preliminary scale. This was sent with the feedback form (Fig. 1) to experts from several teaching and research offices including one member of the committee of Shanghai standardized residency program. Before completing the feedback form, the purpose and significance of the research were clearly explained to them and instructions for completion were provided. The experts were asked to read the scale carefully and then complete the questionnaire. They were also asked to identify any difficult or ambiguous questions in the scale and whether the wording of each item was clear.

\section{Surgery recording}

All pterygium surgeries were performed in theatre by pterygium excision and conjunctival autograft transplantation and all necessary instruments were placed on the sterile operating platform. For each resident, the entire procedure was recorded and stored using a highdefinition video system. Videos of residents from the first, second and third years of the residency program were randomly selected using a stratified sampling method. Eight such videos recorded pterygium surgery were chosen. These videos were conducted by two first year, three second year and three third year residents.

\section{Reliability and repeatability of the assessment scale}

Twenty senior surgeons from different specialties formed an expert evaluation team, each independently viewing the eight videos and completing the evaluation scale. The experts were masked to residents' rotation level during the evaluation. Three months later, each expert was asked to repeat this process, viewing each video and completing the scale for each. To minimize recollection of the first evaluation, the order in which videos were viewed differed between the two occasions. Intraclass correlation coefficient (ICC) was used to test interrater reliability and intra-rater repeatability $[14,15]$. ICC ranges from 0 to 1 , with higher values indicating better reliability. ICC values greater than 0.7 were considered to indicate reliability $[16,17]$. SPSS 23.0 software (IBM) was used for statistical analysis, and $P<0.05$ was considered statistically significant.

\section{Construct validity of the assessment scale}

After reliability testing, the scale was applied in examination of residents conducting pterygium surgery. The 12 items in the scale were organized into three categories including basic surgical skills (five items: preoperative preparation, local anesthesia, microscope use, instrument handling, and postoperative clean up); pterygium dissection (four items: conjunctival incision, pterygium head dissection, pterygium body separation and dissection and remove of subconjunctival tissue; and ocular surface reconstruction (three items: hemostasis, conjunctival autograft acquisition, and autograft suturing). All 12 items were scored independently. Amos software (version 24; SPSS, Inc., Chicago, IL, USA) was used and the values of Chi squared $\left(\mathrm{X}^{2}\right)$, degrees of freedom $(\mathrm{df})$, goodness of fit index (GFI), adjusted goodness of fit index (AGFI), average variance extracted (AVE), composite reliability $(\mathrm{CR})$, and root mean square error of approximation (RMSEA) were calculated to evaluate the construct validity of the scale $[18,19]$.

\section{Results}

\section{Refinement of the assessment scale}

Nineteen experts completed the questionnaire. Five experts suggested including the assessment of "preoperative preparation and post-operative management" because these skills are included in the video, and are part of the surgical procedure. Three experts suggested modified wording more conducive to understanding. Seven experts suggested using three independent items including "pterygium head dissection", "pterygium body 
part dissection" and "removal of residual pterygium" to replace "pterygium dissection", for detailed evaluation of surgery. Two experts suggested adding "hemostasis" to the scale, because it is an important skill in pterygium surgery and can affect prognosis. Five experts suggested removing the assessment of "intraoperative complications" from the scale due to likely inaccuracies in assessment. Each expert's opinions and suggestions were fully considered, and those deemed appropriate were included in the evaluation scale. Further rounds of feedback and modification were made until all surgeons agreed on the final scale. In this way, face and content validity were achieved from these surgeons' suggestions [3].

The final assessment scale is shown in Table 1. The scale included five basic surgical skills (preoperative preparation, microscope use, instrument handling, local anesthesia and postoperative management) and seven pterygium surgical skills (conjunctival incision, pterygium head dissection, pterygium body part separation, removal of residual pterygium, hemostasis, conjunctival autograft acquisition, suturing). Each item was rated on a 5-point Likert scale, with each point anchored by behavioral descriptors.

\section{Reliability and repeatability of the assessment scale}

The 20 expert surgeons who viewed the videos and completed evaluation for each had specialties in cataract (4), glaucoma (2), cornea (4), strabismus (2) and retinal disease (8). Fifteen of the 20 repeated this process 3 months later. A total of 280 evaluation scales (160 on the first occasion and 120 on the second) were completed. All experts said that they were able to complete the scale within a 5 -min period.

The interrater reliability of each item and overall score, including all 20 evaluators involved on the first occasion, are shown in Table 2. All ICC values of all items including the total score were greater than 0.8 (0.852-0.992), and $69 \%$ of the data were greater than

1. Are the instructions self-explanatory?

Comments

2. Is the rating scale appropriate?

Comments



3. Does the rating scale include all the factors

essential to evaluate operative performance?

Comments

4. Is the "Microscope use" item appropriate?

Comments

5. Is the "Instrument handling" item appropriate?

Comments

6 . Is the "Local anesthesia" item appropriate?

Comments

7. Is the "Conjunctival incision" item appropriate?

Comments

8. Is the "Pterygium dissection" item appropriate?

Comments

9. Is the "Conjunctival autograft acquisition" item appropriate?

Comments

10. Is the "Autograft suturing" item appropriate?

Comments

11. Is the "Intraoperative complications" item appropriate?

Comments

12. Is there anything else should be included in the form (keeping in mind the goal of minimum time expenditure)?

Comments

Yes No

Fig. 1 Questionnaire sent to experts to determine the face and content validity of the assessment scale 
Table 1 Assessment Scale for Pterygium Surgery

\begin{tabular}{|c|c|c|c|c|c|c|}
\hline DATE RESIDENT EVALUATOR & 1 & 2 & 3 & 4 & 5 & Score \\
\hline Preoperative preparation & $\begin{array}{l}\text { Failed to wear hat, } \\
\text { mask and gloves }\end{array}$ & $\begin{array}{l}\text { Failed to wear two } \\
\text { of the three }\end{array}$ & $\begin{array}{l}\text { Failed to wear } \\
\text { one of the three }\end{array}$ & $\begin{array}{l}\text { Wearing hat, } \\
\text { mask and gloves } \\
\text { correctly }\end{array}$ & $\begin{array}{l}\text { Wearing hat, mask and } \\
\text { gloves smoothly }\end{array}$ & \\
\hline Microscope use & $\begin{array}{l}\text { Off-center and } \\
\text { refocusing } \\
\text { constantly }\end{array}$ & $\begin{array}{l}\text { Off-center and } \\
\text { refocusing } \\
\text { frequently }\end{array}$ & $\begin{array}{l}\text { Out of center and } \\
\text { focus occasionally }\end{array}$ & $\begin{array}{l}\text { Stay in center } \\
\text { and focus } \\
\text { constantly }\end{array}$ & $\begin{array}{l}\text { Fluid moves with } \\
\text { microscope }\end{array}$ & \\
\hline Instrument handling & $\begin{array}{l}\text { Constantly makes } \\
\text { tentative and } \\
\text { awkward moves } \\
\text { with inappropriate } \\
\text { use of instruments }\end{array}$ & $\begin{array}{l}\text { Frequently makes } \\
\text { tentative and } \\
\text { awkward moves } \\
\text { with instruments }\end{array}$ & $\begin{array}{l}\text { Fair use of } \\
\text { instruments but } \\
\text { occasionally stiff } \\
\text { or awkward }\end{array}$ & $\begin{array}{l}\text { Competent use } \\
\text { of instruments }\end{array}$ & $\begin{array}{l}\text { Fluid moves with } \\
\text { instruments }\end{array}$ & \\
\hline Local anesthesia & $\begin{array}{l}\text { Unable to complete; } \\
\text { does not } \\
\text { understand the } \\
\text { injection site and } \\
\text { dose of lidocaine }\end{array}$ & $\begin{array}{l}\text { Barely completed; } \\
\text { the dose and site } \\
\text { were not } \\
\text { appropriate }\end{array}$ & $\begin{array}{l}\text { Almost } \\
\text { completed; the } \\
\text { dose and site } \\
\text { were almost } \\
\text { appropriate }\end{array}$ & $\begin{array}{l}\text { Completed; the } \\
\text { dose and site } \\
\text { were appropriate }\end{array}$ & $\begin{array}{l}\text { Smoothly completed; } \\
\text { injection of anesthetics } \\
\text { under bulbar } \\
\text { conjunctiva of } \\
\text { pterygium body with } \\
\text { accurate dose }\end{array}$ & \\
\hline Conjunctival incision & $\begin{array}{l}\text { Failed to make the } \\
\text { incision }\end{array}$ & $\begin{array}{l}\text { Barely made the } \\
\text { incision; the location } \\
\text { and length were } \\
\text { not appropriate }\end{array}$ & $\begin{array}{l}\text { Almost } \\
\text { completed; the } \\
\text { location and } \\
\text { length were } \\
\text { almost } \\
\text { appropriate }\end{array}$ & $\begin{array}{l}\text { Completed; the } \\
\text { location and } \\
\text { length were } \\
\text { appropriate }\end{array}$ & $\begin{array}{l}\text { Smoothly completed; } \\
\text { incision was made } 1 \\
\text { mm outside and parallel } \\
\text { to the limbus. The } \\
\text { length of the incision } \\
\text { was } 0.5 \mathrm{~mm} \text { across the } \\
\text { upper and lower edges } \\
\text { of pterygium }\end{array}$ & \\
\hline Pterygium head dissection & Failed to dissect & $\begin{array}{l}\text { Less than } 60 \% \text { of } \\
\text { pterygium head was } \\
\text { dissected from } \\
\text { cornea }\end{array}$ & $\begin{array}{l}60 \text { to } 80 \% \text { of } \\
\text { pterygium head } \\
\text { was dissected } \\
\text { from cornea }\end{array}$ & $\begin{array}{l}\text { More than } 80 \% \\
\text { of pterygium } \\
\text { head was } \\
\text { dissected from } \\
\text { cornea }\end{array}$ & $\begin{array}{l}\text { Fully dissected } \\
\text { pterygium head from } \\
\text { cornea in its anatomical } \\
\text { plane }\end{array}$ & \\
\hline $\begin{array}{l}\text { Pterygium body separation } \\
\text { and dissection }\end{array}$ & $\begin{array}{l}\text { Failed to separate } \\
\text { pterygium body } \\
\text { from conjunctiva } \\
\text { and sclera }\end{array}$ & $\begin{array}{l}\text { Less than } 60 \% \text { of } \\
\text { pterygium body was } \\
\text { separated and } \\
\text { dissected from } \\
\text { conjunctiva }\end{array}$ & $\begin{array}{l}60 \text { to } 80 \% \text { of } \\
\text { pterygium body } \\
\text { was separated } \\
\text { and dissected } \\
\text { from conjunctiva }\end{array}$ & $\begin{array}{l}\text { More than } 80 \% \\
\text { of pterygium } \\
\text { body was } \\
\text { separated and } \\
\text { dissected from } \\
\text { conjunctiva }\end{array}$ & $\begin{array}{l}\text { Fully dissected } \\
\text { pterygium body from } \\
\text { conjunctiva without } \\
\text { damaging episcleral } \\
\text { vessels }\end{array}$ & \\
\hline $\begin{array}{l}\text { Removal of subconjunctival } \\
\text { tissue }\end{array}$ & Failed to remove & $\begin{array}{l}\text { Less than } 60 \% \text { of } \\
\text { subconjunctival } \\
\text { tissue was removed }\end{array}$ & $\begin{array}{l}60 \text { to } 80 \% \text { of } \\
\text { subconjunctival } \\
\text { tissue was } \\
\text { removed }\end{array}$ & $\begin{array}{l}\text { More than } 80 \% \\
\text { of } \\
\text { subconjunctival } \\
\text { tissue was } \\
\text { removed }\end{array}$ & $\begin{array}{l}\text { Full removal of } \\
\text { fibrovascular tissue } \\
\text { leaving a thin and } \\
\text { smooth conjunctival rim }\end{array}$ & \\
\hline Hemostasis & $\begin{array}{l}\text { Failed to complete } \\
\text { hemostasis; the } \\
\text { operation field is } \\
\text { unclear }\end{array}$ & $\begin{array}{l}\text { Barely completed, } \\
\text { the hemostasis was } \\
\text { not timely and } \\
\text { effective }\end{array}$ & $\begin{array}{l}\text { Almost } \\
\text { completed, the } \\
\text { hemostasis was } \\
\text { almost timely and } \\
\text { effective }\end{array}$ & $\begin{array}{l}\text { Completed, the } \\
\text { hemostasis is } \\
\text { timely and } \\
\text { effective }\end{array}$ & $\begin{array}{l}\text { Perfectly completed } \\
\text { hemostasis with minimal } \\
\text { use of cautery }\end{array}$ & \\
\hline $\begin{array}{l}\text { Conjunctival autograft } \\
\text { acquisition }\end{array}$ & Failed to obtain & $\begin{array}{l}\text { The size and } \\
\text { location of } \\
\text { the conjunctival } \\
\text { autograft was not } \\
\text { appropriate; } \\
\text { irregular cut in } \\
\text { borders or } \\
\text { buttonhole of the } \\
\text { graft }\end{array}$ & $\begin{array}{l}\text { The size and } \\
\text { location of } \\
\text { the conjunctival } \\
\text { autograft was } \\
\text { almost } \\
\text { appropriate; some } \\
\text { residual Tenon's } \\
\text { on the graft }\end{array}$ & $\begin{array}{l}\text { The size and } \\
\text { location of } \\
\text { the conjunctival } \\
\text { autograft was } \\
\text { appropriate; few } \\
\text { residual Tenon's } \\
\text { on the graft }\end{array}$ & $\begin{array}{l}\text { Perfect size and location } \\
\text { of the conjunctival } \\
\text { autograft; thin and even } \\
\text { graft }\end{array}$ & \\
\hline Autograft suturing & $\begin{array}{l}\text { Failed to suture, or } \\
\text { sutured the graft } \\
\text { upside and down }\end{array}$ & $\begin{array}{l}\text { Sutures are } \\
\text { completed with } \\
\text { difficulty; the graft is } \\
\text { not well secured by } \\
\text { sutures }\end{array}$ & $\begin{array}{l}\text { Sutures are } \\
\text { completed with } \\
\text { little difficulty; the } \\
\text { graft is almost } \\
\text { secured by } \\
\text { sutures }\end{array}$ & $\begin{array}{l}\text { Sutures are } \\
\text { completed } \\
\text { properly; the } \\
\text { graft is secured } \\
\text { by sutures }\end{array}$ & $\begin{array}{l}\text { Smooth and perfect } \\
\text { suturing with good } \\
\text { space and tension }\end{array}$ & \\
\hline Postoperative clean up & Failed to clean the & Failed to do two of & Failed to do one & Completed all of & Disposed of medical & \\
\hline
\end{tabular}


Table 1 Assessment Scale for Pterygium Surgery (Continued)

\begin{tabular}{llllll}
\hline DATE RESIDENT EVALUATOR & $\mathbf{1}$ & $\mathbf{2}$ & $\mathbf{3}$ & $\mathbf{4}$ & $\mathbf{5}$ \\
\hline $\begin{array}{l}\text { table. Failed to } \\
\text { settle the } \\
\text { microscope and } \\
\text { instruments. Failed } \\
\text { to remove hat, mask } \\
\text { and gloves properly }\end{array}$ & the three things & $\begin{array}{l}\text { of the three } \\
\text { things }\end{array}$ & the three things & $\begin{array}{l}\text { waste in correct bins. } \\
\text { Settled the microscope } \\
\text { and instruments. } \\
\text { Removed the hat, mask } \\
\text { and gloves correctly }\end{array}$ \\
\end{tabular}

If the description of a score cannot be satisfied, a lower grade of score will be allotted

0.9. The "local anesthesia" item showed the highest interrater reliability $(0.992,95 \%$ CI $0.982-0.998)$.

Table 3 shows intra-rater reliability (repeatability) of each evaluator. The ICC values of all items and total score were greater than 0.8 , and $62 \%$ of the data were greater than 0.9, the item "conjunctival autograft acquisition" showing the highest repeatability $(0.962,95 \%$ confidence interval 0.945-0.974).

\section{Validity of the assessment scale}

Construct validity of 257 assessment scales was analyzed (Table 4). In this classification model, the $x^{2} /$ $\mathrm{df}=2.699<3$, goodness of fit index $(\mathrm{GFI})=0.931>0.9$ and adjusted goodness of fit index (AGFI) $=0.902>$ 0.9 , which means that model fit is fair. Average variance extracted (AVE) was used to reflect convergent validity. The AVE values of the three categories (basic surgical skills, pterygium dissection and ocular surface reconstruction) were $0.584,0.571$ and 0.631 . CR values were $0.874,0.842$ and 0.835 , and the RMSEA value was $0.043<0.05$. These results showed good construct validity.

\section{Discussion}

At the beginning of the 21st century, ophthalmology training in China remains nonsystematic, and the quality of training varies between hospitals. In an effort to address this situation, Shanghai established standardized training programs for junior residents (in 2010) and senior residents (in 2014). Those programs play an extremely important role in ensuring the professional standard of ophthalmologists and the quality of indispensable medical services. The ophthalmologist Training Committee of Shanghai standardizes these programs into 3 years of training, the final year of which includes evaluation of surgical skills. In Shanghai, assessment of junior residents' surgical skill is based on their ability to suture corneal ruptures on pig eyes, and senior residents' skills are assessed by performance of pterygium excision and conjunctival autograft transplantation in theatre. We have previously developed an assessment scale for the process of suturing corneal rupture, and its validity and reliability have been confirmed in practice [13]. However, the assessment of pterygium surgery remains subjective and is prone to factors such as unconscious

Table $\mathbf{2}$ Interrater reliability of twenty observers for pterygium surgery assessing scale

\begin{tabular}{llll}
\hline & ICC & $\mathbf{9 5 \% ~ C l}$ & Upper bound \\
\cline { 3 - 4 } & & Lower bound & 0.969 \\
Preoperative preparation & $0.871^{* * *}$ & 0.693 & 0.998 \\
Microscope use & $0.992^{* * *}$ & 0.982 & 0.975 \\
Instrument handling & $0.895^{* * *}$ & 0.750 & 0.965 \\
Local anesthesia & $0.852^{* * *}$ & 0.647 & 0.978 \\
Conjunctival incision & $0.908^{* * *}$ & 0.780 & 0.985 \\
Pterygium head dissection & $0.973^{* * *}$ & 0.850 & 0.984 \\
Pterygium body separation and dissection & $0.933^{* * *}$ & 0.841 & 0.971 \\
Removal of subconjunctival tissue & $0.904^{* * *}$ & 0.771 & 0.994 \\
Hemostasis & $0.976^{* * *}$ & 0.944 & 0.967 \\
Conjunctival autograft acquisition & $0.863^{* * *}$ & 0.673 & 0.980 \\
Autograft suturing & $0.914^{* * *}$ & 0.795 & 0.982 \\
Postoperative clean up & $0.924^{* * *}$ & 0.819 & \\
\hline ICC intaclass corration coeffici & & \\
\end{tabular}

ICC intraclass correlation coefficient, $\mathrm{Cl}$ confidential interval

${ }^{* * *} P<0.001$ 
Table 3 Intrarater reliability (repeatability) for pterygium surgery assessing scale

\begin{tabular}{llll}
\hline Item & ICC & $\mathbf{9 5 \%} \mathbf{C l}$ & Upper bound \\
\cline { 3 - 4 } & & Lower bound & 0.941 \\
Preoperative preparation & $0.916^{* * *}$ & 0.879 & 0.947 \\
Microscope use & $0.923^{* * *}$ & 0.890 & 0.919 \\
Instrument handling & $0.883^{* * *}$ & 0.832 & 0.893 \\
Local anesthesia & $0.846^{* * *}$ & 0.779 & 0.926 \\
Conjunctival incision & $0.894^{* * *}$ & 0.847 & 0.940 \\
Pterygium head dissection & $0.914^{* * *}$ & 0.876 & 0.954 \\
Pterygium body separation and dissection & $0.934^{* * *}$ & 0.905 & 0.889 \\
Removal of subconjunctival tissue & $0.841^{* * *}$ & 0.772 & 0.974 \\
Hemostasis & $0.962^{* * *}$ & 0.945 & 0.936 \\
Conjunctival autograft acquisition & $0.909^{* * *}$ & 0.869 & 0.887 \\
Autograft suturing & $0.837^{* * *}$ & 0.767 & 0.936 \\
Postoperative clean up & $0.908^{* * *}$ & 0.867 & \\
\hline
\end{tabular}

ICC intraclass correlation coefficient, $\mathrm{Cl}$ confidential interval

${ }^{* * *} P<0.001$

bias $[12,20]$. Therefore, a critical need exists for a valid and reliable assessment tool.

In this study, we designed an evaluation scale for pterygium surgery conducted in China. The principles of the design are: (1) feasibility (rapid and easy to use); (2) whole-procedure evaluation; (3) surgical skill assessment at different rotation levels; (4) feedback and summative evaluation to improve skills and competencies. The final scale consists of 12 items, including five on basic surgical techniques and seven on pterygium surgery. The scale uses a 5-point Likert scoring system, and each score has a detailed score description. Zarei-Ghanavati et al. [3] also developed an assessment rubric for pterygium surgery. Our scale is similar to theirs in structure, but different in content. For example, we included the evaluation of basic surgical skills such as microscope use and instrument handling since they are important aspects of microsurgery. However, items beyond resident level such as Mitomycin-C application and fibrin glue usage are not included. In the scale, percentage score categories such as $60 \%, 80 \%$ were used, for more accurate and objective evaluation of the scale. Moreover, the scale is relatively simple and all evaluators reported completion within a period of $5 \mathrm{~min}$, suggesting that it can be applied in rapid and large-scale resident assessment. More importantly, Zarei-Ghanavati et al. did not test the construct validity and repeatability level of their scale. In this study, the scale was completed 537 times ( 280 for reliability and 257 for validity), and validity as well as reliability were demonstrated. For validity, a level of face and content validity was established by considering all comments and incorporating appropriate

Table 4 The construct validity of the scale

\begin{tabular}{|c|c|c|c|c|c|c|c|}
\hline & & & Estimate & S.E. & $P$ & AVE & CR \\
\hline Preoperative preparation & $<--$ & Basic surgical skills & 0.640 & & & 0.584 & 0.874 \\
\hline Local anesthesia & $<--$ & Basic surgical skills & 0.753 & 0.118 & $<0.001$ & & \\
\hline Microscope use & $<--$ & Basic surgical skills & 0.731 & 0.107 & $<0.001$ & & \\
\hline Instrument handling & $<--$ & Basic surgical skills & 0.762 & 0.106 & $<0.001$ & & \\
\hline Postoperative clean up & $<--$ & Basic surgical skills & 0.911 & 0.116 & $<0.001$ & & \\
\hline Conjunctival incision & $<--$ & Petrygium dissection & 0.739 & & & 0.571 & 0.842 \\
\hline Pterygium head dissection & $<--$ & Petrygium dissection & 0.753 & 0.099 & $<0.001$ & & \\
\hline Pterygium body separation and dissection & $<--$ & Petrygium dissection & 0.768 & 0.086 & $<0.001$ & & \\
\hline Removal of residual pterygium & $<--$ & Petrygium dissection & 0.763 & 0.094 & $<0.001$ & & \\
\hline Hemostasis & $<---$ & Ocular surface reconstruction & 0.781 & & & 0.631 & 0.835 \\
\hline Conjunctival autograft acquisition & $<--$ & Ocular surface reconstruction & 0.682 & 0.074 & $<0.001$ & & \\
\hline Autograft suturing & $<---$ & Ocular surface reconstruction & 0.904 & 0.098 & $<0.001$ & & \\
\hline
\end{tabular}

S.E. Standard error, AVE Average variance extracted, CR Composite reliability 
suggestions into the assessment scale. Good construct validity found using GFI, AGFI, AVE, CR and RMSEA. We used Intraclass correlation coefficient (ICC) to test interrater reliability and intra-rater reliability. Although ICC is something of a blunt tool, any disagreement greater than 1 point among teachers would represent a major problem. Fortunately, this problem only occurred twice, when one same teacher evaluated one same student. The two assessment items were "instrument handling" and "local anesthesia". The scores given by the teacher was two points worse than those given by some other teachers. The student is a first-year resident without much surgical experience, and the teacher is a very strict supervisor. She was more rigorous than other teachers in score evaluation, which might lead to the score gap. Nevertheless, all ICC values of all items were more than 0.8. Note that ICC values greater than or equal to 0.75 indicate high reliability $[17,21]$.

In this study, we developed a comprehensive and widely applicable assessment scale to assess the key components of pterygium surgery. The scale will provide a practical and standardized scoring method for resident examination, and the pass mark of each item can be set as $>3$ points. It uses an analytical scoring system, including observable and measurable components of surgery. This will help educators to reduce the subjectivity of evaluation, record any weaknesses and give appropriate, individualized feedback based on the assessment scale. It is hoped that this tool will provide a structured template for other programs to evaluate residents' surgical skills.

\begin{abstract}
Abbreviations
ICO: International Council of Ophthalmology; ICC: Intraclass correlation coefficient; $x^{2}$ : Chi squared; $d f$ : Degrees of freedom; GFI: Goodness of fit index; AGFI: Adjusted goodness of fit index; AVE: Average variance extracted;
\end{abstract} CR: Composite reliability; RMSEA: Root mean square error of approximation

\section{Acknowledgements}

Not applicable.

\section{Authors' contributions}

$\mathrm{ZZ}$ and $\mathrm{HL}$ : conception of the paper and preparation of the first draft of the paper; TQ and BZ: study design and conduct; ZZ and TQ: data collection and analysis; $X S$ and $X X$ : data interpretation and revision of the paper. All authors read and approved the final manuscript.

\section{Funding}

None.

\section{Availability of data and materials}

The datasets used and/or analysed during the current study available from the corresponding author on reasonable request.

\section{Declarations}

Ethics approval and consent to participate

The need for ethics approval and the need for consent were waived by the Ethics Committee of Shanghai General Hospital.

Consent for publication

Not applicable.

\section{Competing interests}

The authors declare that they have no competing interests.

\section{Author details}

'Department of Ophthalmology, Shanghai General Hospital, Shanghai Jiao Tong University, 100 Haining Road, Hongkou District, 200080 Shanghai,

China. ${ }^{2}$ National Clinical Research Center for Eye Diseases, Shanghai, China.

${ }^{3}$ Shanghai Key Laboratory of Ocular Fundus Diseases, Shanghai, China.

${ }^{4}$ Shanghai Engineering Center for Visual Science and Photomedicine,

Shanghai, China. ${ }^{5}$ Shanghai Engineering Center for Precise Diagnosis and

Treatment of Eye Disease, Shanghai, China.

Received: 7 February 2021 Accepted: 8 September 2021

Published online: 27 September 2021

\section{References}

1. Lee AG, Carter KD. Managing the new mandate in resident education: a blueprint for translating a national mandate into local compliance. Ophthalmology. 2004;111(10):1807-12.

2. Taylor JB, Binenbaum G, Tapino P, Volpe NJ. Microsurgical lab testing is a reliable method for assessing ophthalmology residents' surgical skills. $\mathrm{Br}$ J Ophthalmol. 2007;91(12):1691-4.

3. Zarei-Ghanavati M, Ghassemi H, Salabati M, Mahmoudzadeh R, Liu C, Daniell $M$, et al. A surgical skills assessment rubric for pterygium surgery. Ocul Surf. 2020;18(3):494-8.

4. Fisher JB, Binenbaum G, Tapino P, Volpe NJ. Development and face and content validity of an eye surgical skills assessment test for ophthalmology residents. Ophthalmology. 2006;113(12):2364-70.

5. Juniat V, Golnik KC, Bernardini FP, Cetinkaya A, Fay A, Mukherjee B, et al. The Ophthalmology Surgical Competency Assessment Rubric (OSCAR) for anterior approach ptosis surgery. Orbit. 2018;37(6):401-4.

6. Pilling RF, Bradbury JA, Reddy AR. Strabismus surgical skills assessment tool: development of a surgical assessment tool for strabismus surgery training. Am J Ophthalmol. 2010;150(2):275-8 e2.

7. Saleh GM, Gauba V, Mitra A, Litwin AS, Chung AK, Benjamin L. Objective structured assessment of cataract surgical skill. Arch Ophthalmol. 2007; 125(3):363-6.

8. Golnik KC, Beaver H, Gauba V, Lee AG, Mayorga E, Palis G, et al. Cataract surgical skill assessment. Ophthalmology. 2011;118(2):427 e1-5.

9. Golnik KC, Haripriya A, Beaver H, Gauba V, Lee AG, Mayorga E, et al. Cataract surgical skill assessment. Ophthalmology. 2011;118(10):2094-4 e2.

10. Clearfield E, Hawkins BS, Kuo IC. Conjunctival Autograft Versus Amniotic Membrane Transplantation for Treatment of Pterygium: Findings from a Cochrane Systematic Review. Am J Ophthalmol. 2017;182:8-17.

11. Scott DJ, Valentine RJ, Bergen PC, Rege RV, Laycock R, Tesfay ST, et al. Evaluating surgical competency with the American Board of Surgery inTraining Examination, skill testing, and intraoperative assessment. Surgery. 2000;128(4):613-22.

12. Moorthy K, Munz Y, Sarker SK, Darzi A. Objective assessment of technical skills in surgery. BMJ. 2003;327(7422):1032-7.

13. Zhang Z, Zhou M, Liu K, Zhu B, Liu H, Sun X, et al. Development of a new valid and reliable microsurgical skill assessment scale for ophthalmology residents. BMC Ophthalmol. 2018;18:68

14. Koch GG. Intraclass correlation coefficient. In: Kotz S, Johnson NL, editors. Encyclopedia of statistical sciences 4. New York: Wiley; 1982. p. 213-7.

15. Mehta S, Bastero-Caballero RF, Sun Y, Zhu R, Murphy DK, Hardas B, et al. Performance of intraclass correlation coefficient (ICC) as a reliability index under various distributions in scale reliability studies. Stat Med. 2018;37: 2734-52.

16. Zaki R, Bulgiba A, Nordin N, Azina Ismail N. A systematic review of statistical methods used to test for reliability of medical instruments measuring continuous variables. Iran J Basic Med Sci. 2013;16:803-7.

17. Barraquer Rl, Pinilla Cortés L, Allende MJ, Montenegro GA, Ivankovic B, D'Antin JC, et al. Validation of the nuclear cataract grading system BCN 10 Ophthalmic Res. 2017;57(4):247-51.

18. Rappaport LM, Amstadter AB, Neale MC. Model fit estimation for multilevel structural equation models. Struct Equ Modeling. 2020;27:318-29.

19. Ryu E. Model fit evaluation in multilevel structural equation models. Front Psychol. 2014;5:81

20. Mills RP, Mannis MJ. American Board of Ophthalmology Program Directors' task force on competencies. Report of the American Board of 
Ophthalmology Task Force on the competencies. Ophthalmology. 2004;111: $1267-8$.

21. Dong J, Jia YD, Wu Q, Zhang S, Jia Y, Huang $D$, et al. Interchangeability and reliability of macular perfusion parameter measurements using optical coherence tomography angiography. Br J Ophthalmol. 2017;101: $1542-9$

\section{Publisher's Note}

Springer Nature remains neutral with regard to jurisdictional claims in published maps and institutional affiliations.

Ready to submit your research? Choose BMC and benefit from:

- fast, convenient online submission

- thorough peer review by experienced researchers in your field

- rapid publication on acceptance

- support for research data, including large and complex data types

- gold Open Access which fosters wider collaboration and increased citations

- maximum visibility for your research: over $100 \mathrm{M}$ website views per year

At $\mathrm{BMC}$, research is always in progress.

Learn more biomedcentral.com/submissions 